\title{
Stosunki majątkowe między parafią zakonną a domem zakonnym
}

Stosunki majątkowe między parafią zakonną a domem zakonnym należą do nieopracowanych zagadnień nauki prawa kanonicznego, nie tylko polskiego ${ }^{1}$. Zdecydowało o tym wiele czynników .Przede wszystkim trudność materii, która obejmuje szereg kwestii z zakresu: prawa zakonnego, prawa ustroju hierarchicznego Kościoła, prawa majątkowego i kanonizowanego prawa cywilnego. Z drugiej strony, w wielu przypadkach praktyka wymaga odpowiedzi kanonistów. Artykuł ten ma pomóc w rozwiązywaniu konkretnych problemów.

Przez parafię zakonną należy rozumieć parafię powierzoną kleryckiemu instytutowi zakonnemu albo kleryckiemu stowarzyszeniu życia apostolskiego ${ }^{2}$, zgodnie z kan. 520 Kodeksu prawa kanonicznego ${ }^{3}$. Natomiast dom zakonny oznacza dom

${ }^{1} \mathrm{~W}$ znanych podręcznikach przedmiotu bądź brak jest wzmianki na ten temat, bądź ogranicza się ona jedynie do pół strony tekstu; por. V. De Paolis, I beni temporali della Chiesa, Bologna 2001, passim; J.-P. Schouppe, Elementi di diritto patrimoniale canonico, Milano 2008, s. 217-218.

${ }^{2} \mathrm{~W}$ dalszych rozważaniach pominięty zostanie przymiotnik ,klerycki” (jako oczywisty) oraz odniesienie do stowarzyszenia życia apostolskiego. W literaturze zauważa się, że nie ma podstaw prawnych, aby wyłączyć z tej instytucji prawnej kleryckie instytuty świeckie z prawem inkardynacji (por. kan. $715 \S 2$ KPK), nawet bez aprobaty Stolicy Apostolskiej; zob. W. Aymans, K. Mörsdorf, Kanonisches Recht. Lehrbuch aufgrund des Codex Iuris Canonici, t. 2: Verfassungsrecht und Vereinigungsrecht, hrsg. W. Aymans, Paderborn 1997, s. 422; A. Mendonça, Entrusting of a parish to a religious institute and appointment of a religious priest as parish priest, „Forum” (Valetta) 16 (2005) nr 1, s. 131.

${ }^{3}$ Dalej w skrócie: KPK. Kanon ten w tłumaczeniu polskim stanowi: „§ 1. Osoba prawna nie powinna być proboszczem. Jednakże za zgodą kompetentnego przełożonego biskup diecezjalny, nie zaś administrator diecezji, może powierzyć parafię [paroeciam committere] kleryckiemu instytutowi zakonnemu lub kleryckiemu stowarzyszeniu życia apostolskiego, erygując ją nawet w kościele instytutu lub stowarzyszenia, ale na tej zasadzie, że jeden prezbiter będzie proboszczem parafii, albo, w przypadku powierzenia parafii kilku solidarnie, moderatorem, o którym w kan. $517, \S 1$. 2 . Powierzenie parafii [paroeciae commissio], o którym w $\S 1$, może być dokonane na stałe lub na ściśle określony 
prawnie ustanowiony wspólnoty zakonnej, która pozostaje pod władzą lokalnego przełożonego (por. kan. $608 \mathrm{KPK}$, pars prima () $^{5}$.

\section{Stosunki prawne między parafią zakonną a domem zakonnym: źródła prawa i zasady}

Powierzenie parafii instytutowi zakonnemu dokonuje się na podstawie umowy, zgodnie z kan. 520 KPK. Umowa ta zawierana jest między dwoma osobami prawnymi - diecezją, w której parafia jest ustanowiona na sposób trwały (por. kan. 515 $\S 1 \mathrm{KPK}), \mathrm{i}$ instytutem zakonnym ${ }^{6}$. Umowa jest dwustronna ${ }^{7}$, ale stosunek prawny, który się z niej rodzi, nie jest bynajmniej prosty. Biorą w nim bowiem udział aż cztery osoby prawne. $Z$ jednej strony są to diecezja (por. kan. $373 \mathrm{KPK}$ ) i parafia (por. kan. 515 § $3 \mathrm{KPK}$ ), która staje się zakonna. $Z$ drugiej zaś strony uczestniczą

czas. W obydwu przypadkach ma to być uczynione na podstawie pisemnej umowy zawartej pomiędzy biskupem diecezjalnym i kompetentnym przełożonym instytutu lub stowarzyszenia. Obok innych spraw należy w niej wyraźnie i dokładnie określić to, co dotyczy wypełniania posługi, przydzielonych do tego osób oraz spraw ekonomicznych".

${ }^{4}$ Przepis ten w tłumaczeniu polskim stanowi: „Zakonna społeczność winna mieszkać w domu prawnie ustanowionym, pozostając pod władzą przełożonego wyznaczonego zgodnie z przepisem prawa”. W prawie własnym instytutów zakonnych taki dom może być nazywany np. konwentem czy domem (jak w prawie dominikańskim) albo klasztorem.

${ }^{5}$ Co do pojęć por. P. Skonieczny, Kim jest proboszcz zakonny? O relacji między przełożonym zakonnym a proboszczem w parafii powierzonej instytutowi zakonnemu, „Annales Canonici” 10 (2014), s. 59-80.

${ }^{6}$ Co prawda przepis kan. $520 \S 1$ KPK stanowi w verba legis, że umowa zawierana jest między „biskupem diecezjalnym” a instytutem zakonnym. Jednakże w rzeczywistości chodzi o umowę między dwoma osobami prawnymi - tą, której część stanowi parafia powierzana, tj. diecezją, oraz inną, której z kolei parafia jest powierzana, a zatem - instytutem zakonnym. Tak, słusznie, część literatury kanonistycznej, por. A. Palmieri, Parishes entrusted to the care of religious: starting afresh from Christ, [w:] Canon Law Society of America proceedings 2002, Washington DC 2002, s. 216, 227; $\mathrm{V}$. Mamede, O convênio entre os bispos diocesanos e os superiores maiores dos institutos religiosos clericais a teor do cânone 520 \& 2, „Commentarium pro Religiosis et Missionariis” 84 (2003) nr 1-4, s. 105; J.-P. Schouppe, Elementi..., dz. cyt., s. 218.

Wskazanie wprost biskupa diecezjalnego jako strony umowy w paragrafie pierwszym jest usprawiedliwione tym, że ustawodawcy chodziło o wyłączenie w tym zakresie kompetencji administratora diecezji. W paragrafie drugim tegoż kanonu pierwszeństwo przyznano względowi praktycznemu, wymieniając wprost reprezentantów osób prawnych zawierających umowę - biskupa diecezjalnego (por. kan. 393 KPK) i właściwego przełożonego instytutu zakonnego (według postanowień prawa własnego). Tej techniki legislacyjnej nie można pochwalić, gdyż zaciemnia ona obraz tego, kim są - z punktu widzenia prawnego - strony stosunku umownego.

${ }^{7}$ Inaczej o trójstronnym stosunku prawnym (biskup dicezjalny - instytut zakonny - proboszcz zakonny), zob. B. Primetshofer, Relacje prawne między klasztorem a parafia przy klasztornym kościele parafialnym, [w:] Stużba i praca. Materiaty II Międzynarodowego Sympozjum Prawa Zakonnego (Lublin, 17-18 X 1994), red. B. W. Zubert, E. Szczot, Lublin 1996, s. 156. 
w tym stosunku prawnym instytut zakonny (w praktyce najczęściej jego prowincja) i dom zakonny, który powstaje przy parafii, a w chwili zawierania umowy może jeszcze nie istnieć w sensie prawnym (por. kan. $634 \S 1$ KPK). Przedmiotem dalszych rozważań będzie stosunek majątkowo-prawny na poziomie najniższym, lokalnym - między parafią zakonną a domem zakonnym. To bowiem na tym poziomie rodzą się najistotniejsze problemy majątkowe.

W treści umowy między diecezją a instytutem zakonnym (prowincją) należy ustalić nie tylko kwestie posługi (przedmiot stosunku umownego) ${ }^{8}$ i osoby przeznaczone do jej wykonywania (zazwyczaj zakonnicy) ${ }^{9}$, ale również sprawy majątkowe (por. kan. $520 \S 2$ KPK). Stąd umowa ta, ale też postanowienia prawa własnego instytutu zakonnego oraz prawo partykularne diecezji ${ }^{10} \mathrm{i}$, rzecz jasna, regulacje powszechnego prawa kanonicznego, zwłaszcza w kwestiach majątkowych, w tym kanonizowana ustawa cywilna - muszą być brane pod uwagę przy omawianiu zagadnienia i rozstrzyganiu wątpliwości ${ }^{11}$. W interpretacji przepisów prawa kanonicznego pomaga również tradycja kanoniczna (por. kan. $6 \S 2 \mathrm{KPK}$ ).

U podstaw relacji prawnych, także w zakresie kwestii majątkowych, między stronami umowy, ale też między parafią zakonną i domem zakonnym, stoją zasady prawne, którymi należy kierować się przy rozwiązywaniu kwestii szczegółowych. Tymi zasadami prawnymi wspomnianych stosunków prawnych są: zasada dobra dusz, zasada dialogu, zasada legalności oraz zasada sprawiedliwości i słuszności kanonicznej ${ }^{12}$. Bardziej ogólnie rzecz biorąc, można stwierdzić, że fundament wzajemnych relacji między parafią zakonną a domem zakonnym tworzą dwa filary - autonomia obu osób prawnych (poszanowanie podmiotowości prawnej) oraz ich współpraca dla dobra dusz.

${ }^{8}$ Trzeba wziąć pod uwagę okoliczności miejsca, np. opiekę duszpasterską nad znajdującym się na terenie parafii szpitalem czy domem opieki społecznej lub też administrację szkołą parafialną; zob. A. Palmieri, Parishes..., dz. cyt., s. 217.

${ }^{9}$ Chodzi o liczbę minimalną i maksymalną zakonników przeznaczonych do posługi w parafii zakonnej; por. tamże, s. 217-218. Nie można też wykluczyć sytuacji nadzwyczajnej i sprzecznej $\mathrm{z}$ celem zasadniczym umowy, tj. powierzenia tej posługi prezbiterowi spoza instytutu zakonnego (np. diecezjalnemu), gdyby ilość zakonników tak bardzo spadła w instytucie, że nie mógłby on zapewnić tej posługi; zob. V. Mamede, O convênio..., dz. cyt., s. 87-88.

${ }^{10}$ Co do prawa diecezjalnego postuluje się w doktrynie wydanie specjalnych norm odnośnie do zarządu dobrami doczesnymi parafii powierzonej instytutowi zakonnemu; por. A. Mendonça, Entrusting..., dz. cyt., s. 136.

${ }^{11}$ Zob. P. Skonieczny, Kim jest proboszcz ..., dz. cyt., s. 62-64; A. Palmieri, Parishes..., dz. cyt., s. 217.

${ }^{12}$ Zasady te, z wyjątkiem pierwszej z wymienionych, jako zasady prawne umowy zostały sformułowane w literaturze przedmiotu; por. V. Mamede, O convênio ..., dz. cyt., s. 84-85. Zasada sprawiedliwej równowagi, sformułowana przez Mamedego, odpowiada zasadzie „zachowania materii zakonnej”, o której w innym artykule Autora (por. P. Skonieczny, Kim jest proboszcz..., dz. cyt., s. 66-68) i która to zasada nie dotyczy analizowanego tutaj zagadnienia. 


\section{Autonomia}

\subsection{Zasada}

W literaturze kanonistycznej nie ulega wątpliwości, że należy wyraźnie oddzielić majątek dwóch odrębnych osób prawnych, tj. parafii zakonnej i domu zakonnego ${ }^{13}$. Każda z tych osób prawnych ma prawo do nabywania, posiadania, zarządzania czy alienowania dóbr doczesnych Kościoła (por. kan. $1254 \S 1$ i $1255 \mathrm{KPK})^{14}$, które w obu przypadkach są dobrami kościelnymi w rozumieniu kan. 1257 KPK.

Rozdział majątków obu osób prawnych dotyczy nie tylko sytuacji, kiedy dom zakonny powstaje w już istniejącej parafii, stającej się zakonną, ale również w parafii, która powstaje przy domu zakonnym ${ }^{15}$. W każdym razie zgodnie z zasadą sprawiedliwości należy od początku wskazać, co jest przedmiotem praw każdego z podmiotów prawa tego stosunku prawnego.

\subsection{Odrębna księgowość}

\subsubsection{Odrębny inwentarz}

To, co stanowi składnik masy majątkowej parafii zakonnej, powinno być wyraźnie wskazane w inwentarzu (tzw. środki trwałe). Wymóg tego inwentarza wynika z kan. 1283n. 2 i 3 KPK. Inwentarz taki powinien zawierać spis nieruchomości i ruchomości, będących przedmiotem jakichkolwiek praw parafii (własność, użytkowanie wieczyste itp. - ze wskazaniem wpisów w księdze wieczystej, jeżeli chodzi o nieruchomości ${ }^{16}$ ), wraz z ewentualnymi obciążeniami (np. hipoteka, zastaw). W takim inwentarzu należy uwzględnić także kosztowności i dobra kultury, z opisem i podaniem wartości. Inwentarz powinien być aktualizowany. Jest on zazwyczaj załącznikiem umowy o powierzeniu parafii instytutowi zakonnemu ${ }^{17}$.

Odpowiedni inwentarz powinien być sporządzony również przez dom zakonny, zwłaszcza jeżeli to w jego dobrach kościelnych będzie ustanowiona parafia. Prawo własne instytutu zakonnego często przewiduje odpowiednie normy w tym przedmiocie ${ }^{18}$.

\footnotetext{
${ }^{13}$ Zob. A. Mendonça, Entrusting..., dz. cyt., s. 136; V. Mamede, O convênio..., dz. cyt., s. 91, 93;

${ }^{14}$ Bliżej o tym prawie jako prawie wrodzonym Kościoła zob. D. Albornoz Pavisic, I diritti nativi della Chiesa nel Codice di Diritto Canonico e nel diritto concordatario vigente, Roma 2008, s. 89-95.

${ }^{15}$ Por. A. Palmieri, Parishes..., dz. cyt., s. 218-219.

${ }^{16}$ Por. V. Mamede, O convênio..., dz. cyt., s. 91.

${ }^{17}$ Przykładowo: w praktyce amerykańskiej n. 3 wzorca umownego Archidiecezji w Filadelfii (por. A. Palmieri, Parishes..., dz. cyt., s. 228); w praktyce brazylijskiej ust. 2 wzorca umownego (por. V. Mamede, O convênio..., dz. cyt., s. 99).

${ }^{18}$ Przykładowo zob. n. 68 Statutu Prowincji Polskiej Zakonu Braci Kaznodziejów (Dominikanów).
} 


\subsubsection{Własne dochody i rozchody}

Konsekwencją odrębnej osobowości prawnej jest konieczność wyodrębnienia dochodów ${ }^{19}$ i rozchodów parafii zakonnej i domu zakonnego. Umowa między diecezją a instytutem zakonnym powinna zawierać postanowienia w przedmiocie dochodów, aby uniknąć rozbieżności interpretacyjnych ${ }^{20}$.

Źródłami dochodów parafii są co do zasady ${ }^{21}$ : ofiary składane przez wiernych podczas Mszy św. i innych nabożeństw (taca), dobrowolne ofiary składane przez osoby fizyczne, osoby prawne oraz inne jednostki organizacyjne na cele parafialne, inne ofiary składane na działalność związaną z duszpasterstwem prowadzonym przez parafię.

Do dochodów domu zakonnego z kolei należą: ofiary mszalne 22 ; ofiary składane przez wiernych przy okazji sprawowania sakramentów i sakramentaliów (iura stolae) ${ }^{23}$; ofiary składane podczas wizyty duszpasterskiej (kolędy); wypominki; opłatki ${ }^{24}$; wynagrodzenia, emerytury i renty oraz inne dochody zakonników zamieszkałych

${ }^{19}$ Precyzyjniej byłoby użyć terminu ,przychody”. Dochód bowiem jest przychodem pomniejszonym o koszty jego uzyskania.

${ }^{20}$ Podobnie zresztą jak postanowienia odnośnie do dochodów „diecezji” czy „,prowincji instytutu zakonnego", niebędące przedmiotem niniejszego artykułu, np. w przedmiocie zbiórek na cele diecezjalne i ogólnokościelne oraz zbiórek na cele ogólnozakonne oraz na seminarium duchowne (zob. kan. 264 KPK co do podatku seminaristicum), zbiórek na potrzeby misyjne, na Katolicki Uniwersytet Lubelski Jana Pawła II i kościelne wydziały teologiczne, zbiórek na chrześcijan w Ziemi Świętej (Boży Grób w Jerozolimie), ofiar składanych przy okazji mszy św. binowanych i trynowanych oraz zbiorowych (por. kan. $951 \S 1$ KPK; Kongregacja ds. Duchowieństwa, Dekret Mos iugiter o intencjach zbiorowych, 22 II 1991, „Acta Apostolicae Sedis” [dalej: AAS] 83 [1991], s. 444-445; Papieska Komisja ds. Autentycznej Interpretacji Kodeksu Prawa Kanonicznego, Odpowiedź, 6 VIII 1987, AAS 79 [1987], s. 1132).

${ }^{21}$ Por. P. Kaleta, Zadania zarządcy majątku kościelnego w Kodeksie Prawa Kanonicznego z 1983 roku $i$ w polskich synodach diecezjalnych, Lublin 2012, s. 136-138.

${ }^{22}$ Rozumiane też jako ofiary zwyczajowo przysługujące kapłanowi sprawującemu mszę św., np. tzw. opfergang na Górnym Śląsku.

${ }^{23}$ Tak bowiem należy rozumieć kan. 531 i kan. 551 KPK odnośnie do przekazywania do kasy parafialnej ofiar z okazji wykonywania funkcji parafialnych. Ofiary te mają być przeznaczone na utrzymanie proboszcza i wikariuszy parafialnych, chyba że inna była intencja ofiarodawcy. Zob. C. Burgazzi, Il sostentamento del clero. Indagine storico-giuridica, con particolare riferimento alla formazione dei canoni 1272-1274-1275 del Codex Iuris Canonici 1983 e alla loro applicazione in ambito europeo, Roma 2002, s. 208-209; J. Krukowski, Komentarz do kan. 531, [w:] J. Dyduch, W. Góralski, E. Górecki, J. Krukowski, M. Sitarz, Komentarz do Kodeksu Prawa Kanonicznego, t. II/1: Księga II. Lud Boży. Część I. Wierni chrześcijanie. Część II. Ustrój hierarchiczny Kościoła, red. J. Krukowski, Poznań 2005, s. 436, t. 1. Inaczej por. B. Primetshofer, Relacje..., dz. cyt., s. 166. Autor opowiada się za postanowieniem umownym w tym zakresie. Natomiast ofiary (w tym taca) na kościół, będący własnością domu zakonnego, powinny być odrębnie księgowane jako dochód tego domu; por. tamże, s. 168, przyp. 42.

${ }^{24}$ Według praktyki redemptorystów tylko połowa ofiar z kolędy, wypominek i opłatków należy się zakonnikom; por. Z. Podlecki, Niektóre aspekty relacji prawnych miedzy klasztorem a parafia przy klasztornym kościele parafialnym, „Roczniki Nauk Prawnych” 9 (1999) z. 2, s. 68. 
stale w domu zakonnym; inne ofiary składane przez osoby fizyczne, osoby prawne oraz inne jednostki organizacyjne na dom zakonny.

Powyższy wykaz dochodów parafii zakonnej i domu zakonnego wydaje się oczywisty i nierodzący konfliktów. W praktyce jednak również i te kwestie rodzą problemy ${ }^{25}$.

Odrębność kas (dochodów i rozchodów) parafii zakonnej i domu zakonnego często jest regulowana $\mathrm{w}$ umowach oraz $\mathrm{w}$ prawie partykularnym diecezji czy też w prawie własnym instytutu zakonnego ${ }^{26}$.

\subsubsection{Odrębna sprawozdawczość}

Zasada autonomii parafii zakonnej i domu zakonnego przejawia się nie tylko w odrębności mas majątkowych i dochodów, ale też - konsekwentnie - w odrębnej sprawozdawczości. Obowiązek takiej sprawozdawczości domu zakonnego znajduje podstawę prawną w kan. $636 \S 2 \mathrm{KPK}$, ewentualnie kan. $637 \mathrm{KPK}$, a poza tym w prawie własnym instytutu zakonnego ${ }^{27}$. Co do obowiązku sprawozdawczego z zarządu parafią zakonną należy stosować przepisy kan. $1284 \S 2$, n. 8 oraz kan. $1287 \S 1 \mathrm{KPK}$, a nadto prawo diecezjalne, do czego odsyłają umowy o powierzeniu parafii instytutowi zakonnemu.

\subsection{Odrębny zarząd}

Wyodrębnienie księgowości parafii i domu zakonnego, będące skutkiem odrębnej osobowości prawnej, pociąga też za sobą odrębną administrację czy zarząd obu mas majątkowych. Literatura $\mathrm{w}$ tym przedmiocie jest jasna ${ }^{28}$.

Stąd zarząd dóbr doczesnych domu zakonnego sprawowany jest tylko przez przeora z pomocą ekonoma zakonnego (zob. kan. 634 § 1 i kan. $636 \S 1$ KPK oraz postanowienia prawa własnego ${ }^{29}$ ).

Natomiast dobrami doczesnymi parafii zakonnej zarządza tylko proboszcz $\mathrm{z}$ pomocą parafialnej rady ekonomicznej (zob. kan. 532, pars secunda w zW. z kan. 537 oraz kan. $1279 \S 1 \mathrm{KPK})^{30}$. Jasne jest zatem, że to proboszcz wraz z parafialną

${ }^{25}$ O tym niżej, III.3.

${ }^{26}$ Na przykład n. 27 Statutu Ekonomicznego Prowincji Polskiej Zakonu Braci Kaznodziejów (Dominikanów).

${ }^{27}$ W prawie dominikańskim zob. n. 562-572 Księgi Konstytucji i Zarządzeń Braci Zakonu Kaznodziejów [dalej: KKZ].

${ }^{28}$ Tak zwłaszcza kard. Valesio De Paolis, będący największym autorytetem w tej dziedzinie jako specjalista od prawa zakonnego i od prawa majątkowego Kościoła; por. V. De Paolis, Schema tipo di convenzione per l'affidamento delle parrocchie ai religiosi, „Informationes SCRIS” 12 (1986), s. 249.

${ }^{29} \mathrm{~W}$ prawie dominikańskim na przykład zob. n. $544 \mathrm{KKZ}$.

${ }^{30}$ Por. B. Giacon, I beni temporali nelle parrocchie religiose, „Palestra del Clero” 51 (1972) n. 23, s. 1461, 1463. 
radą ekonomiczną decydują o sposobie i celu wydatkowania środków finansowych parafii ${ }^{31}$.

Wydaje się jednak, że zasada odrębnego zarządu parafią zakonną i domem zakonnym jest łagodzona przez zasadę współpracy dla dobra dusz, jeżeli chodzi o sposób sprawowania tego zarządu, o czym poniżej.

\section{Współpraca dla dobra dusz}

3.1. Sposób zarządu dobrami kościelnymi parafii zakonnej:

z uwzględnieniem norm prawa własnego instytutu zakonnego

Wyżej została potwierdzona zasada odrębnego zarządu parafią zakonną i domem zakonnym. Należy zatem określić sposób tego zarządu dobrami kościelnymi parafii zakonnej, w szczególności zaś odpowiedzieć na pytanie, czy proboszcz zakonny może samodzielnie decydować o wydatkowaniu pieniędzy w sumie przekraczającej wysokość ustanowioną $\mathrm{w}$ prawie własnym instytutu zakonnego.

Przywoływany już kan. 532 KPK z 1983 roku stanowi:

W załatwianiu wszystkich czynności prawnych proboszcz występuje w imieniu parafii, zgodnie z przepisami prawa. Ma również troszczyć się o to, by dobra parafii były administrowane według norm kan. 1281-1288 [dotyczą zarządu dóbr doczesnych Kościoła ${ }^{32}$ ].

Do tego też przepisu odsyła kan. 537 KPK, stanowiący:

W każdej parafii powinna być rada do spraw ekonomicznych, która rządzi się nie tylko przepisami prawa powszechnego, lecz także normami wydanymi przez biskupa diecezjalnego. Wierni dobrani

${ }^{31}$ Zob. V. De Paolis, Il consiglio parrocchiale per gli affari economici e i beni patrimoniali della parrocchia, [w:] La parrocchia, Città del Vaticano 1997, s. 267-288. Zgodnie z powyższymi zasadami gospodarzem miejsca (budynku kościoła i obejścia bądź budynku i otoczenia klasztornego) jest zarządca tej osoby prawnej, do której należy w sensie prawnym (jako przedmiot własności lub innego prawa, np. użyczenia) dany budynek czy miejsce. Jeżeli zatem to parafia jest podmiotem praw wobec nieruchomości budynkowej i gruntowej, w jakiejkolwiek formie prawnej, to w praktyce będzie to oznaczało, iż to proboszcz (jako organ osoby prawnej - parafii), a nie przełożony domu zakonnego, będzie działał wobec organów administracji państwowej, jeżeli sprawa dotyczy tych nieruchomości (np. wycinka drzewa, pozwolenie na budowę itp.). W podobnym duchu należy odpowiedzieć na pytanie odnośnie do troski o inne miejsca święte w parafii (np. cmentarz czy kapliczki).

${ }^{32}$ Słuszna krytyka tego odesłania, zawężonego do niektórych tylko przepisów zamiast do całej Księgi V KPK, zob. V. De Paolis, Il consiglio ..., dz. cyt., s. 285. 
zgodnie z tymi normami świadczą proboszczowi pomoc w administrowaniu dobrami parafialnymi, z zachowaniem przepisu kan. 532.

W przepisach tych nie wspomina się o normach prawa własnego instytutu zakonnego, które miałyby wiązać proboszcza zakonnego w wykonywaniu przez niego zarządu dobrami kościelnymi parafii zakonnej. Stąd niekiedy w literaturze ogranicza się zarząd dobrami doczesnymi Kościoła przez proboszcza zakonnego do tego, co stanowią przepisy kodeksowe oraz umowa między diecezją a instytutem zakonnym o powierzeniu parafii zgodnie z kan. $520 \mathrm{KPK}^{33}$.

Taki pogląd jest jednak błędny przynajmniej z kilku powodów. Przede wszystkim należy powołać się na zasadę dzieła instytutu zakonnego, tj. że prowadzenie parafii zostało powierzone instytutowi zakonnemu, a nie proboszczowi jako takiemu, o czym wyraźnie stanowi kan. $520 \S 1 \mathrm{KPK}^{34}$. Diecezja może liczyć na to, że w zarządzanie parafią zakonną i jej dobrami zaangażowane zostaną doświadczenie i autorytet instytutu zakonnego, właśnie dlatego że proboszczem parafii zakonnej jest członek tego instytutu. W ten sposób instytut zakonny daje większe gwarancje bezpiecznego zarządu dobrami parafialnymi ${ }^{35}$.

Ponadto wspomnieć wypada o zasadzie ,zachowania materii zakonnej”, czyli charakteru zakonnego - tak samego dzieła jako takiego (tu: parafii „zakonnej”), jak i poszczególnych zakonników zaangażowanych w to dzieło (tu: proboszcza „zakonnego" - kan. $675 \S 1$ i kan. $678 \S 2 \mathrm{KPK})^{36}$. Nic proboszcza zakonnego nie zwalnia z przestrzegania prawa zakonnego, tym bardziej jeśli chodzi o podejmowanie decyzji majątkowych, które przecież mogą pociągnąć za sobą odpowiedzialność cywilnoprawną instytutu zakonnego za działania zakonnika.

Stąd biorąc pod uwagę wyżej wskazane zasady powierzania parafii instytutowi zakonnemu, w literaturze kanonistycznej słusznie przyjmuje się pogląd, że w administracji dobrami parafialnymi proboszcz zakonny - niezależnie od przestrzegania prawa powszechnego Kościoła i prawa diecezjalnego - powinien także przestrzegać procedur zakonnych ${ }^{37}$. Podobną regulację znaleźć można zazwyczaj w prawie

${ }^{33}$ Por. F. D’Ostilio, Il parroco religioso. Origine ed evoluzione storica della parrocchia eligiosa. Figura giuridica del parroco religioso, Città del Vaticano 2000, s. 146; brak jasności u Remigiusza Sobańskiego, por. R. Sobański, Powierzenie parafi zakonnikom wg motu proprio „Ecclesiae Sanctae”, „Prawo Kanoniczne” 11 (1968) nr 1-2, s. 78.

${ }^{34}$ Omówienie zasady dzieła instytutu zakonnego zob. P. Skonieczny, Kim jest proboszcz..., dz. cyt., s. 65-66.

${ }^{35}$ Por. V. De Paolis, Schema ..., dz. cyt., s. 251.

${ }^{36}$ Zasada ta została skomentowana w innym artykule autora, por. P. Skonieczny, Kim jest proboszcz..., dz. cyt., s. 66-68.

${ }^{37}$ Zob. B. Giacon, I beni temporali..., dz. cyt., s. 1460, 1462; V. De Paolis, Schema ..., dz. cyt., s. $250-251$. 
własnym instytutu zakonnego ${ }^{38}$. Ponadto umowy o powierzeniu parafii instytutowi zakonnemu powinny wyraźnie odwoływać się w tym zakresie do prawa własnego instytutu ${ }^{39}$.

Odnośnie do prawa własnego instytutów zakonnych zwykle w tzw. statutach ekonomicznych znajduje się wyraźne postanowienie, nakazujące proboszczom zakonnym zarządzającym dobrami parafialnymi zwrócenie się po odpowiednie pozwolenia wymagane prawem własnym instytutu zakonnego, zanim nastąpi wszczęcie odpowiedniej procedury w porządku diecezjalnym. Ten obowiązek proboszcza zakonnego ma podstawę prawną w kan. $678 \S 2 \mathrm{KPK}^{40}$. Takie pozwolenie ma charakter nihil obstat - udziela się go bądź nie. Władze instytutu zakonnego bowiem nie mogą merytorycznie ingerować w projekt parafialny. Co najwyżej mogą coś sugerować i po zmianach proboszcz zakonny może ponownie ubiegać się o pozwolenie według procedury zakonnej ${ }^{41}$. Zastrzega się w końcu wyraźnie, że niezależnie od tego typu wewnętrznej procedury ani prowincja, ani dom zakonny nie ponoszą odpowiedzialności cywilnej za działania proboszcza zakonnego ${ }^{42}$.

Podsumowując, proboszcz zakonny nie może samodzielnie decydować o wydatku w sumie przekraczającej wysokość ustanowioną w prawie własnym instytutu zakonnego. Wiąże go w tym zakresie nie tylko prawo powszechne Kościoła i prawo ustanowione przez biskupa diecezjalnego, ale i prawo własne instytutu zakonnego.

To może stanowić dla proboszcza zakonnego pewną niedogodność. Ponosi on bowiem pewne wydatki związane ze swoją funkcją. Zgodnie z kan. 678 § 2 KPK ze wszystkim i za każdym razem powinien udawać się do przełożonego lokalnego czy wyższego po stosowne pozwolenia. Stąd w prawie własnym instytutu należałoby odpowiednio uregulować tę kwestię, udzielając proboszczowi zakonnemu uprawnienia do dysponowania środkami do pewnej wysokości ${ }^{43}$.

${ }^{38}$ Przykładowo w prawie dominikańskim n. 591 KKZ stanowi: ,Sprawy większej wagi, chociażby nie wymagały wydatków ze strony Zakonu, jako finansowane z subwencji pochodzacych z zewnatrz [jak na przykład w przypadku inwestycji czy wydatków podejmowanych przez parafię dominikańską, za którą działa proboszcz dominikański - P.S.], także wymagają należnej zgody, według przepisów n. 590 i poprzedniego artykułu [tj. nn. 585-589 KKZ]”.

${ }^{39}$ Tak we wzorcu umowy Wikariatu Rzymu z 1985 roku, n. 9; por. V. De Paolis, Schema..., dz. cyt., s. 136 .

${ }^{40}$ Przepis ten w thumaczeniu polskim stanowi: „W wykonywaniu zewnętrznego apostolatu zakonnicy podlegają także własnym przełożonym oraz winni pozostawać wierni dyscyplinie instytutu. W razie potrzeby sami biskupi powinni pilnować zachowania tego obowiązku".

${ }^{41}$ Regulacje tego typu znane są w niektórych instytutach zakonnych we Włoszech; por. V. De Paolis, Schema ..., dz. cyt., s. 251, w tym w dominikańskiej, północno-włoskiej Prowincji św. Dominika (zob. Statut tejże Prowincji według stanu prawnego na rok 2009, n. 73 § III).

${ }^{42}$ Tak przykładowo w praktyce amerykańskiej n. 5 wzorca umownego Archidiecezji w Filadelfii (por. A. Palmieri, Parishes..., dz. cyt., s. 228).

${ }^{43}$ Nie wydaje się jednak celowe, by te kwoty, którymi mógłby dysponować swobodnie proboszcz zakonny, miały być równe ani - tym bardziej - większe od tych, którymi dysponuje przełożony lokalny. 


\subsection{Podział kosztów}

\subsubsection{Budynek domu zakonnego będący przedmiotem własności parafii zakonnej}

Przedmiotem postanowień umowy (o powierzeniu parafii instytutowi zakonnemu lub innej specjalnej umowy, do której odsyłałaby ta umowa z kan. $520 \mathrm{KPK}$ ) powinny być przede wszystkim koszty utrzymania nieruchomości albo nakłady ponoszone na nieruchomość, należące do innej osoby prawnej (np. plebanii, która stała się domem zakonnym, a jest własnością parafii zakonnej). Stosunek prawny między właścicielem nieruchomości stającej się domem zakonnym a instytutem zakonnym to użyczenie ${ }^{44}$, jak to jest zazwyczaj praktykowane między kościelnymi osobami prawnymi ${ }^{45}$. W tym zakresie należy stosować kanonizowaną ustawę cywilną polską, tj. art. 710-717 k.c. (por. kan. 1290 KPK).

Wydaje się, że należy wykluczyć jakąkolwiek umowę odpłatną (np. najem, w którym najemcą byłby dom zakonny, zobowiązany do zapłaty czynszu za plebanię $\left.{ }^{46}\right)$. Z samej bowiem istoty umowy o powierzeniu parafii instytutowi zakonnemu wynika, iż jej beneficjentem jest przede wszystkim parafia (od teraz: zakonna) oraz diecezja, nawet jeżeli sam instytut zakonny jest zainteresowany tym rodzajem pracy w diecezji. Przede wszystkim zaś należy mieć na względzie zasadę dobra dusz. Ten właśnie wzgląd duszpasterski wyklucza jakąkolwiek formę odpłatności za używanie budynku plebanii zajmowanego przez dom zakonny.

Praktycznie rzecz ujmując, należałoby w umowie poruszyć kwestię kosztów utrzymania i nakładów na taki budynek plebanii, obecnie zaś domu zakonnego,

Mogłoby to bowiem stworzyć wrażenie dwuwładzy w domu zakonnym, a przecież nie o to chodziłoby ustawodawcy zakonnemu. Samego problemu zaś nie da się rozwiązać poprzez zarząd delegowany czy deputowany, udzielony proboszczowi zakonnemu, o którym przykładowo mowa w prawie dominikańskim (n. 544 KKZ). Nie chodzi bowiem o kwestię zarządu, gdyż ten nie przysługuje podmiotom władzy instytutu zakonnego, a jedynie proboszczowi zakonnemu. Nawet bowiem gdyby przyjąć taką możliwość, to przecież taka delegacja zarządu wymaga uzyskania stosownej zgody w porządku prawa własnego instytutu zakonnego (por. n. $590 \mathrm{KKZ}$ ).

${ }^{44}$ Zgodnie z definicją ustawową zawartą $\mathrm{w}$ art. 710 polskiego kodeksu cywilnego [dalej: k.c.]: „Przez umowę użyczenia użyczający zobowiązuje się zezwolić biorącemu, przez czas oznaczony lub nie oznaczony, na bezpłatne używanie oddanej mu w tym celu rzeczy". Podstawową cechą użyczenia jest jego czasowość i nieodpłatność; por. W. Czachórski, Zobowiązania. Zarys wykładu, Warszawa 1994, s. 335.

${ }^{45}$ Użyczenie jest podstawą relacji prawnych między diecezją a instytutem zakonnym w praktyce we Włoszech (zob. n. 8 wzorca umownego Wikariatu Rzymu z 1985 roku: uso gratuito; por. V. De Paolis, Schema ..., dz. cyt., s. 135-136) i w Brazylii (zob. ust. 12 wzorca umownego: comodato; por. V. Mamede, O convênio ..., dz. cyt., s. 101).

${ }^{46}$ Zgodnie bowiem z art. 659 § 1 k.c. „Przez umowę najmu wynajmujący zobowiązuje się oddać najemcy rzecz do używania przez czas oznaczony lub nie oznaczony, a najemca zobowiązuje się płacić wynajmującemu umówiony czynsz". 
a ponadto problem utrzymania nieruchomości gruntowej, na której posadowiony jest ten budynek.

W literaturze przedmiotu przyjmuje się, że w sytuacji zajmowania przez dom zakonny budynku plebanii, która nie jest przedmiotem własności jakiejkolwiek osoby prawnej zakonnej, koszty „zwyczajnego" utrzymania tego budynku obciążają dom zakonny, natomiast koszty nadzwyczajne - parafię zakonną ${ }^{47}$. Ten pogląd znajduje dodatkowe uzasadnienie w kanonizowanej ustawie cywilnej polskiej ${ }^{48}$. Warto w umowie przewidzieć, co rozumie się przez pojęcie kosztów zwyczajnych i nadzwyczajnych, jak również i to, że to parafia zakonna ponosi koszty remontów nadzwyczajnych budynku zajmowanego przez dom zakonny. Zawsze zaś przed większymi nakładami (np. remontem) warto prosić o zgodę właściciela budynku (parafię lub diecezję), a to pod rygorem niemożności ewentualnego żądania zwrotu poniesionych nakładów ${ }^{49}$.

Strony umowy mogą ustalić, że koszty zarządu nieruchomością gruntową wokół posadowionej na niej budowli domu zakonnego (np. pielęgnacja zieleni, odśnieżanie, ubezpieczenie od odpowiedzialności cywilnej), ponoszą po połowie parafia zakonna i dom zakonny. Trzeba bowiem zauważyć, że nawet jeśli ta część nieruchomości gruntowej jest w posiadaniu domu zakonnego jako osoby prawnej, to zazwyczaj cała aktywność na tej nieruchomości wynika z zaangażowania parafialnego zakonników. Stąd zgodnie z zasadą słuszności kanonicznej także parafia zakonna jako osoba prawna powinna uczestniczyć w kosztach utrzymania tejże nieruchomości.

\subsubsection{Budynek kościoła należący do domu zakonnego}

W tych parafiach zakonnych, w których budynek kościoła jest przedmiotem własności tegoż instytutu, zarząd budynkiem kościoła należy do domu zakonnego. Praktycznie oznacza to, że zarząd ten jest sprawowany przez przełożonego lokalnego tegoż domu (organ tej osoby prawnej), z pomocą swego ekonoma ${ }^{50}$. On też reprezentuje tę osobę prawną wobec organów administracji państwowej właśnie jako mającą prawo do nieruchomości. Ponosi też wszystkie koszty zarządu tą nieruchomością.

Jednakże zgodnie z utrwalonym poglądem doktryny kanonistycznej i tradycją kanoniczną (por. kan. $630 \S 4$ KPK z 1917 roku, pars secunda) parafia zakonna

${ }^{47}$ Tak w n. 12b cyt. wzorca umowy Wikariatu Rzymu z 1985 roku; por. V. De Paolis, Schema ..., dz. cyt., s. 137, 257-258.

${ }^{48}$ Przepis art. 713 k.c. stanowi: „Biorący do używania ponosi zwykłe koszty utrzymania rzeczy użyczonej. Jeżeli poczynił inne wydatki lub nakłady na rzecz, stosuje się odpowiednio przepisy o prowadzeniu cudzych spraw bez zlecenia".

${ }^{49}$ Tak bowiem postanawia kanonizowany art. $754 \mathrm{w}$ zw. z art. 713 k.c., tj. „Kto prowadzi cudzą sprawę wbrew wiadomej mu woli osoby, której sprawę prowadzi, nie może żądać zwrotu poniesionych wydatków i odpowiedzialny jest za szkodę, chyba że wola tej osoby sprzeciwia się ustawie lub zasadom współżycia społecznego".

${ }^{50}$ Tak wprost zob. B. Primetshofer, Relacje..., dz. cyt., s. 165, 168-169. 
uczestniczy w kosztach utrzymania budynku kościoła i otoczenia. Ofiary wiernych (taca i składki) mogą być przeznaczane na remonty i inne prace związane z kościołem i jego otoczeniem. Wynika to stąd, iż to właśnie parafia jest beneficjentem tych nieruchomości, jakkolwiek nie są one przedmiotem jej własności. Co więcej, w przypadku tego typu kościołów - jednocześnie parafialnych i zakonnych - działa też domniemanie, że ofiara jest składana na „kościół”'51.

W literaturze wyrażono nawet pogląd, że parafia powinna także uiszczać pewną kwotę instytutowi zakonnemu za używanie kościoła będącego przedmiotem jego własności ${ }^{52}$. Stąd z punktu widzenia interesu diecezji i parafii zakonnej lepiej kwestię tę uregulować wyraźnie w umowie na zasadzie użyczenia ${ }^{53}$. Samego poglądu zaś nie należy podzielać, a to ze względu na zasadę współpracy dla dobra dusz.

Biorąc pod uwagę przywołaną wyżej tradycję kanoniczną, należy parafię zakonną obciążyć kosztami utrzymania nieruchomości gruntowej (otoczenia kościoła). To bowiem przede wszystkim parafia korzysta $z$ tejże nieruchomości i ze względu na działalność duszpasterską w parafii wierni wchodzą na teren posesji, która powinna być odpowiednio utrzymana (łącznie z ubezpieczeniem od odpowiedzialności cywilnej za nieszczęśliwe wypadki). Oczywiście, byłoby wskazane, aby odpowiednie postanowienia znalazły się $\mathrm{w}$ umowie o powierzeniu parafii instytutowi zakonnemu lub w specjalnej umowie między parafią a domem zakonnym, do której odsyłałaby umowa z kan. 520 KPK.

\subsubsection{Wydatki wspólne}

Nie można wykluczyć sytuacji, w której pewne koszty (np. utrzymania wspólnych nieruchomości, wspólnych uroczystości itp.) muszą być ponoszone razem, zresztą z różnych powodów (np. jeden licznik gazu dla budynku domu zakonnego i połączonego z nim kościoła, wspólne święta patronalne i odpusty itp.). W tych sytuacjach należy zastosować zasadę sprawiedliwości i słuszności kanonicznej oraz zawsze pamiętać o zasadzie współpracy dla dobra dusz.

Zasada sprawiedliwości i słuszności kanonicznej znajduje uszczegółowienie przede wszystkim w znanej w prawie rzymskim zasadzie cui bono oraz w zasadzie następstwa prawnego, obowiązującej w prawie międzynarodowym, a wywodzącej

${ }^{51}$ Por. B. Giacon, I beni temporali..., dz. cyt., s. 1462. Pogląd ten nadal jest aktualny, jakkolwiek został wyrażony pod rządem kan. $1536 \S 1$ KPK z 1917 roku. Podobnie zob. B. Primetshofer, Relacje..., dz. cyt., s. $167-168$.

${ }^{52}$ Zob. R. Sobański, Powierzenie parafii..., dz. cyt., s. 78; V. De Paolis, Vita religiosa e parrocchia. Criteri giuridici, [w:] Vita religiosa e parrocchia. Atti della XXIV Assemblea Generale CISM. Collevalenza 12-16 Novembre 1984, Roma 1985, s. 173; tenże, De paroeciis institutis religiosis commissis vel committendis, „Periodica de Re Morali, Canonica, Liturgica” 74 (1985) nr 1-3, s. 415.

${ }^{53}$ Jak na przykład w praktyce brazylijskiej czy włoskiej (zob. n. 8 wzorca umownego Wikariatu Rzymu z 1985 roku; cyt. V. De Paolis, Schema ..., dz. cyt., s. 135-136; ust. 12 wzorca umownego; cyt. V. Mamede, $O$ convênio ..., dz. cyt., s. 101). 
się z prawa naturalnego. Zasada cui bono oznacza, że za wydatki płaci ten podmiot prawny, który odnosi korzyści, nawet jeśli umowa została zawarta formalnie przez kogoś innego. $Z$ kolei w zasadzie następstwa prawnego chodzi o to, że za zobowiązania poprzedniego proboszcza odpowiada parafia, a nie instytut zakonny czy dom zakonny. Nie można bowiem obarczać zakonnej osoby prawnej, która nie miała żadnych związków z poprzednim proboszczem, zobowiązaniami przez niego zaciągniętymi, nawet jeżeli dotyczą one plebanii, a obecnie budynku klasztornego, chyba że miałaby zastosowanie zasada cui bono ${ }^{54}$.

Przy podziale tych wydatków wspólnych należy przede wszystkim zabiegać o ich sprawiedliwy czy słuszny podział, zgodnie z zasadą autonomii parafii zakonnej i domu zakonnego. W praktyce należałoby założyć liczniki tam, gdzie jest to możliwe, oraz - zgodnie z zasadą cui bono - zdecydować o innych wydatkach wspólnych ${ }^{55}$.

Należy się zgodzić, że nie da się wprowadzić „,matematycznej” sprawiedliwości (na zasadzie absolutnej równości) tych wydatków, których nie da się sensownie podzielić, a których beneficjentami są obie strony stosunku prawnego ${ }^{56}$. Wtedy ma zastosowanie sprawiedliwość i słuszność kanoniczna oraz współpraca dla dobra dusz. W takich sytuacjach można odnieść się do tradycji kanonicznej, która wzmiankowana jest w literaturze pod rządem Kodeksu z 1917 roku, a dotyczy kosztów uroczystości wspólnych (functiones mixtae) parafii zakonnej i domu zakonnego

${ }^{54}$ Przykładowo poprzedni proboszcz zawarł umowę z operatorem telewizji kablowej na czas określony 3 lat. W tym czasie parafia stała się zakonna, a plebania - klasztorem; telewizja kablowa zupełnie nie służy klasztorowi. Taka umowa zawarta przez poprzedniego proboszcza wiązałaby - zgodnie z zasadą następstwa prawnego - parafię, a nie dom zakonny. Inaczej zaś należałoby ocenić na przykład umowę o dostarczanie energii elektrycznej, również zawartą przez poprzedniego proboszcza. Służy ona domowi zakonnemu i stąd - na podstawie zasady cui bono - będzie on nią związany.

${ }^{55}$ Do zobowiązań parafii zatem należałoby w praktyce zaliczyć: podatek od nieruchomości, na której posadowiony jest budynek kościoła, a także wydatki bieżące związane z utrzymaniem tejże nieruchomości (np. ubezpieczenie od odpowiedzialności cywilnej za nieszczęśliwe wypadki, odśnieżanie, pielęgnacja otoczenia, zieleni itp.); koszty zatrudnienia pracowników parafii, świadczących pracę na podstawie umowy o pracę albo innej umowy cywilnoprawnej (składki ubezpieczenia emerytalno-rentowego i zdrowotnego, podatki itp.); utrzymanie samochodu używanego przez proboszcza i wikariuszy parafialnych w celach parafialnych (paliwo, ubezpieczenia, serwisowanie, podatki itp.); koszty utrzymania kościoła (wystrój, komunikanty, sprzątanie itp.).

Natomiast dom zakonny odpowiadałby za należyte wykonywanie następujących zobowiązań, wynikających z bieżących wydatków: woda i kanalizacja (gdyż to przede wszystkim zakonnicy zużywają wodę; pobór wody z kościoła jest zazwyczaj niewielki); wywóz śmieci; koszty zatrudnienia pracowników domu zakonnego, świadczących pracę na podstawie umowy o pracę albo innej umowy cywilnoprawnej (składki ubezpieczenia emerytalno-rentowego i zdrowotnego, podatki itp.); utrzymanie samochodu używanego przez zakonników do celów wyłącznie zakonnych (paliwo, ubezpieczenia, serwisowanie, składki leasingowe, podatki itp.); Internet (chyba że beneficjentem tej usługi jest także parafia).

${ }^{56} \mathrm{~W}$ powołanym na wstępie przykładzie opłat za gaz można przyjąć, że w okresie grzewczym obie strony dzielą się opłatami za gaz po połowie, a poza tym okresem (chodzi o podgrzewanie wody, której kościół nie używa) opłaty te pokrywa tylko dom zakonny. 
(podaje się przykład obiadu odpustowego w uroczystość świętego, który jest nie tylko patronem parafii, ale również instytutu zakonnego $)^{57}$. W tych przypadkach uznaje się, że $2 / 3$ kosztów pokrywa parafia, a resztę - dom zakonny ${ }^{58}$. Przyjmuje się bowiem, że większym beneficjentem jest parafia niż dom zakonny, stąd słuszne jest, aby to parafia w większym stopniu uczestniczyła w kosztach.

W przypadku wspólnych inwestycji parafii zakonnej i domu zakonnego należałoby polecać zawarcie uprzedniej umowy, regulującej zobowiązania każdej ze stron.

\subsection{Niektóre sporne dochody i ich podział}

W literaturze kanonistycznej podnosi się kwestię ofiar wiernych (tacy), dawanych nie ze względu na parafię zakonną, lecz - zakonników. Co do zasady taca w kościele parafialnym przypada parafii (por. kan. $1267 \mathrm{KPK}$ ). Jednak pytanie powstaje w sytuacji, kiedy kościół parafialny jednocześnie jest na przykład sanktuarium albo wcześniej był tylko zakonny, lub też wierni uczęszczają do tego kościoła spoza parafii, wybierając ten kościół ze względu na zakonników ${ }^{59}$.

Należy wtedy - ze sprawiedliwości i słuszności kanonicznej-część tacy przekazać domowi zakonnemu, co powinno być uregulowane w umowie z diecezją expresse et accurate (kan. $520 \S 2 \mathrm{KPK})^{60}$. Gdyby zaś do takiej sytuacji doszło po jakimś czasie od zawarcia umowy o powierzeniu parafii instytutowi zakonnemu (w wyniku na przykład dobrej pracy zakonników, co przekładałoby się na wzrost tacy w kościele parafialnym), to należałoby odpowiednio zmienić umowę, o której mowa w kan. $520 \mathrm{KPK}$. W praktyce niektórych diecezji w umowach zastrzega się specjalną zbiórkę (np. raz w roku, na kwartał czy w miesiącu) przeznaczoną dla domu zakonnego, który prowadzi parafię zakonną ${ }^{61}$.

Kolejne zagadnienie to wynagrodzenie proboszcza i wikariuszy parafialnych w parafii zakonnej. W literaturze przedmiotu nie ulega wątpliwości, że parafia (także zakonna) powinna utrzymywać tak proboszcza, jak i wikariuszy parafialnych (tych

${ }^{57}$ Natomiast nie należą do takich uroczystości wspólnych uroczystości czysto parafialne, jak na przykład wprowadzenie nowego proboszcza zakonnego (kan. 527 § 2 KPK), Boże Ciało czy odpust parafialny, mimo że w uroczystościach tych uczestniczą także zakonnicy. Stąd koszty takich imprez pokrywać powinna w całości parafia zakonna zgodnie z zasadą autonomii i cui bono.

${ }^{58}$ Zob. C. Delgado, De relationibus inter parochum religiosum et eius superiores regulares (cum respecto particulari ad ius speciale O.F.M.), Romae 1940, s. 93-94.

${ }^{59}$ Problem wyraźnie podnosi V. De Paolis, De paroeciis..., dz. cyt., s. 415.

${ }^{60}$ Por. V. De Paolis, Schema ..., dz. cyt., s. 252-253; B. Primetshofer, Relacje ..., dz. cyt., s. 162, przyp. 24, s. 166; Z. Podlecki, Niektóre aspekty..., dz. cyt., s. 68.

${ }^{61}$ Tak na przykład we wzorcu umowy Archidiecezji w Filadelfii (USA), n. 4; por. A. Palmieri, Parishes..., dz. cyt., s. 228. Inni proponują przekazać tacę z nabożeństw klasztornych; B. Primetshofer, Relacje..., dz. cyt., s. 162, przyp. 24; Z. Podlecki, Niektóre aspekty..., dz. cyt., s. 68. Jednak nie da się rozróżnić takich mszy św. klasztornych od parafialnych. Co do sanktuariów, redemptoryści polscy dochody z odpustów dzielą w stosunku 75 proc. na klasztor, a 25 proc. na parafię. 
ostatnich - w stosunku do tego, czy są w parafii na pełnym etacie, czy też na jego części). Prawo do godnego wynagrodzenia duchownego (remuneratio) wynika z kan. $281 \S 1$ i $2 \mathrm{KPK}^{62}$ i powinno ono być takie samo jak wynagrodzenie duchownych diecezjalnych, zgodnie z kan. $1274 \S 1 \mathrm{KPK}^{63}$, gdzie z kolei stanowi się o utrzymaniu duchownych (sustentatio ${ }^{64}$. Obowiązek parafii utrzymania duchownych zakonnych zaangażowanych w pracę parafialną jest niezależny od statusu i sytuacji majątkowej domu czy instytutu zakonnego ${ }^{65}$.

Co więcej, jeżeli proboszcz zakonny korzysta w parafii z pracy jakiegoś współbrata, który formalnie nie jest wikariuszem parafialnym, ex iustitia parafia zakonna powinna mu wynagrodzić za posługę według przyjętych w diecezji stawek czy zwyczajów (np. jedna taca w miesiącu ${ }^{66}$ ). Wówczas wynagrodzenie otrzymuje dom zakonny, a nie sam zakonnik ${ }^{67}$. Ten sam sposób przekazania wynagrodzenia dotyczy proboszcza zakonnego i wikariuszy (może to być kwota stała przelewana co miesiąc na konto domu zakonnego $)^{68}$.

Jako koszty utrzymania proboszcza (wikarego) wymienia się: utrzymanie (wikt i opierunek), zamieszkanie, życie wspólne (tj. koszty usług na rzecz wspólnych

${ }^{62}$ Przepisy kan. 281 § 1 i 2 KPK stanowią: „§ 1. Wypełniając kościelną posługę, duchowni zasługują na wynagrodzenie odpowiednie ich pozycji, z uwzględnieniem zarówno natury ich zadania, jak również okoliczności miejsca i czasu, dzięki któremu mogliby zaspokoić potrzeby własnego życia, a także wynagrodzić tych, których pomocy potrzebują. § 2. Należy także zatroszczyć się, by mieli właściwie zabezpieczoną opiekę społeczną, jeśliby byli dotknięci chorobą, niezdolnością lub starością".

${ }^{63}$ Por. C. Delgado, De relationibus..., dz. cyt., s. 94; R. Sobański, Powierzenie parafii..., dz. cyt., s. 78; V. De Paolis, De paroeciis ..., dz. cyt., s. 415; B. Primetshofer, Relacje ..., dz. cyt., s. 165-166; C. Burgazzi, Il sostentamento ..., dz. cyt., s. 203. Kanon 1274 § 1 KPK stanowi zaś: „W poszczególnych diecezjach powinna istnieć specjalna instytucja, gromadząca dobra i ofiary przeznaczone na utrzymanie duchownych, którzy petnia stużbę dla dobra diecezji, zgodnie z postanowieniem kan. 281, chyba że inaczej temu zaradzono" (kursywa - P.S.).

${ }^{64}$ Oba pojęcia remuneratio i sustentatio są bardzo zbliżone pojęciowo i w zasadzie równoznaczne. Jednak celem wynagrodzenia (remuneratio) z kan. 281 KPK jest utrzymanie (sustentatio) duchownego, o którym mowa w kan. 1274 KPK. O ile remuneratio jest związane z wykonywaniem posługi kościelnej i może być określone jako prawo duchownego, o tyle sustentatio wynika bardziej z więzów inkardynacji (por. kan. 269, n. 1 KPK) i bycia duchownym aniżeli wykonywania swojej posługi (por. kan. $1350 \S 1 \mathrm{KPK}$ ). Zazwyczaj sustentatio jest zagwarantowane przez remuneratio, ale niekoniecznie, gdyż cel sustentatio jest osiągnięty także poprzez ofiary mszy św. oraz iura stolae (por. kan. 282 i kan. $946 \mathrm{KPK}$ ). O ile prawo do sustentatio ma charakter absolutny, o tyle prawo do remuneratio jest relatywne i może być realizowane bezpośrednio (wobec duchownych diecezjalnych) albo pośrednio (wobec duchownych zakonnych - poprzez instytut zakonny). Por. C. Burgazzi, Il sostentamento..., dz. cyt., s. 195-209.

${ }^{65}$ Por. C. Burgazzi, Il sostentamento ..., dz. cyt., s. 204.

${ }^{66}$ Tak Z. Podlecki, Niektóre aspekty..., dz. cyt., s. 69.

${ }^{67}$ Zob. C. Delgado, De relationibus..., dz. cyt., s. 94; Z. Podlecki, Niektóre aspekty ..., dz. cyt., s. $68-69$.

${ }^{68}$ Por. De Paolis, Schema ..., dz. cyt., s. 255. 
pomieszczeń, np. sprzątanie, konserwacja itp.), tzw. kieszonkowe, urlop, koszty ubezpieczenia emerytalnego, rentowego i zdrowotnego ${ }^{69}$. Do konwentu należałyby koszty ściśle osobiste i samego konwentu, jak na przykład koszty rekolekcji zakonnych, wydatki na książki itp. ${ }^{70}$. Zaliczki na podatek dochodowy, wynikające z przepisów prawa polskiego i związane z ich działalnością duszpasterską w parafii zakonnej, powinny być ex iustitia pokrywane przez tę parafię, gdyż to parafia jest beneficjentem pracy zakonników.

Powyższe zasady podziału kosztów utrzymania zakonnika pracującego na rzecz parafii zakonnej oparte są na ogólnym kryterium słusznego utrzymania duchownego diecezjalnego, do czego mają równe prawo także zakonnicy zaangażowani duszpastersko na rzecz diecezji poprzez prowadzenie parafii zakonnej. Chodzi zatem o godne życie, pozwalające na wykonywanie posługi duszpasterskiej. Oznacza to wystarczalność odnośnie do własnych potrzeb, ale i możliwość pomocy innym, zwłaszcza personelowi domu zakonnego (koszty jego zatrudnienia, np. kucharki) oraz najuboższych (możliwość udzielenia jałmużny). Do kosztów tych należy doliczyć ubezpieczenie duchownych (por. kan. $1274 \S 2 \mathrm{KPK})^{71}$.

Gdyby umowa o powierzeniu parafii instytutowi zakonnemu nie regulowała poważnej kwestii wynagrodzenia zakonników pracujących na rzecz parafii zakonnej albo odmawiałaby im wprost takiego prawa, to w tym zakresie umowa ta może budzić poważne wątpliwości co do jej zgodności z kan. 281 KPK oraz z samym prawem Bożym (por. Mt 10, 10; Łk 10, 7; 1 Kor 9, 14; 2 Tes 3, 9) ${ }^{72}$. Wymagałaby zatem zmiany.

\section{Wnioski}

Stosunki majątkowe między parafią zakonną a domem zakonnym powinny być oparte na dwóch fundamentalnych zasadach - autonomii obu osób prawnych oraz współpracy dla dobra dusz. Oczywiście, w praktyce mogą zdarzyć się konflikty, ale przy ich - najlepiej polubownym (kan. 1713-1716 KPK) - rozstrzyganiu powinny pomagać te właśnie zasady, a ponadto cele dóbr kościelnych, o których mowa w kan. 1254 § 2 KPK: kult Boży, godziwe utrzymanie duchownych, duszpasterstwo i caritas.

${ }^{69}$ Tak we wzorcu umowy Wikariatu Rzymu z 1985 roku, n. 11; por. V. De Paolis, Schema..., dz. cyt., s. 136, 256.

${ }^{70}$ Tak zwłaszcza zob. V. De Paolis, Schema ..., dz. cyt., s. 255.

${ }^{71}$ Kryteria te wymieniane są w literaturze przedmiotu; zob. C. Burgazzi, Il sostentamento..., dz. cyt., s. 185.

${ }^{72}$ Zob. V. De Paolis, I beni..., dz. cyt., s. 171-172; C. Burgazzi, Il sostentamento ..., dz. cyt., s. 10-14. 


\section{Summary}

\section{The property relations between the religious parish}

\section{and the religious house}

This article presents the problematic concerning the property relations between the religious parish and the religious house. According to the Author these relations are founded on two basic principles: the autonomy of the two juridical persons, i.e. the religious parish and the religious house, and cooperation in view of the salvation of souls. The Author then applies these basic principles by commenting on income, the administration of goods and, finally, the common costs to be apportioned.

\section{Keywords}

Religious parish, religious house, the temporal goods of the Church 
